\title{
ENVIRONMENTAL POLICY IN CHINA: CHALLENGES AND OPPORTUNITIES
}

\author{
Łukasz Gacek \\ Jagiellonian University in Kraków \\ Institute of Middle East and Far East \\ e-mail: lukasz.gacek@uj.edu.pl
}

\begin{abstract}
China's long-term development plan puts strong emphasis on environmental issues. Chinese government emphasized that the measure of economic growth must take into account the social and environmental costs. Socio-economic development has been coupled with environment protection. The national low-carbon strategy aims at achieving a better balance between the environment protection and economic growth.
\end{abstract}

Key words: China, environmental protection, Environmental policy, Sustainable development

\section{INTRODUCTION}

China is the world's second largest economy, to the United States, by nominal GDP. ${ }^{1}$ Over the last three decades China's spectacular economic growth has been driven by export and investment. The annual rate of GDP growth averaged 9.88\% from 1989 until $2015 .{ }^{2}$ Since 1978 about 700 million rural residents have been lifted out of poverty. ${ }^{3}$ China's rapid economic development has brought about rising

1 In 2014 China overtook the US to become the world's largest economy based on purchasing power parity (PPP). [Gross domestic product 2014, PPP, World Development Indicators database, The World Bank, 29.12.2015, http://databank.worldbank.org/data/download/GDP PPP.pdf (access: 01.02.2016).

2 China GDP Annual Growth Rate 1989-2016, Trading Economics, http://www.tradingeconomics.com/china/gdp-growth-annual (access: 01.02.2016).

3 The poverty rate in the countryside down from $97.5 \%$ ( 770.39 million) in 1978 to $7.2 \%$ (70.17 million) in 2014. The poverty line was set as 2800 yuan in annual income for 2014 . [张为民：脱贫步伐加快 扶贫成效显著我国贫困人口大幅减少 (Zhang Weimin: Tuopin bufa jiakuai fupin chengxiao xianzhu woguo pinkun renkou dafu jianshao), National Bureau of Statistics of the People's Republic of China, 16.10.2015, http://www.stats.gov.cn/tjsj/sjjd/201510/ t20151016_1257098.html (access: 01.02.2016). 
energy consumption and environmental costs. It has surpassed the United States as the world's largest energy consumer. In 2014 it accounted for 23\% of global energy consumption. ${ }^{4}$ China has recognized that for a long time, its development policy did not take into account environmental costs. As a result, both environmental degradation and climate change have generated significant economic costs since 1978, when China began the reform and opening-up campaign. In 2006 Zhu Guangyao, deputy chief of the State Environmental Protection Agency, estimated that pollution cost China $10 \%$ of its GDP (more than 200 billion USD in 2005, when the country's GDP was 2.26 trillion USD). ${ }^{5}$ The Chinese Academy of Science estimated that China's resource and environmental costs (including resource consumption and ecological degradation) even amounted to $13.5 \%$ of GDP in $2005 .{ }^{6}$

The Chinese government is determined to tackle environmental problems by undertaking a number of measures to curb pollution. For several years China consistently implemented a plan that aims to improve the quality of air, water, and soil. However, it is a difficult process, because of existing energy intensive and high polluting industries. Key challenges for the government focus on balancing economic growth with environmental protection. This paper illustrates the scale of current environmental problems and describes the progress and the prospects of China's environmental policies.

\section{PROGRESS OF ENVIRONMENTAL POLICY AND LAWS}

Understanding the importance of environmental issues, China has made institutional and structural changes. In 1988 the Environment Protection Leading Group of the State Council (the first temporary environmental protection organization, established in 1973) was transformed into the Environmental Protection Bureau under the Environmental Protection Department of Urban and Rural Construction. Six years later, the Environmental Protection Bureau was separated from the Ministry of Construction and put directly under the State Council. In 1998 the State Environmental Protection Bureau was upgraded to the Environmental Protection Administration (SEPA). Ten years later it was replaced by the Ministry of Environmental Protection.

4 BP Statistical Review of World Energy, June 2015, http://www.bp.com/content/dam/bp/ pdf/Energy-economics/statistical-review-2015/bp-statistical-review-of-world-energy-2015-fullreport.pdf (access: 01.02.2016).

5 Pollution costs equal 10\% of China's GDP, "China Daily", 06.06.2006.

6 See: 中国经济增长的资源环境代价 (Zhongguo jingji zengzhang de ziyuan huanjing daijia, The Real Price of China's Economic Growth - An Empirical Study of Genuine Savings), 科学 出版社 (China Sciences Press), Beijing, 2009.

7 See: Zhang Shiqiu, The Ministry of Environmental Protection: From Organizational Upgrade to Functional Enhancement, [in:] The China Environment Yearbook, Volume 4: Tragedy and Hope - From the Sichuan Earthquake to the Olympics, Yang Dongping (ed.), Vol. 4, BRILL, Leiden-Boston 2010, p. 208-217. 
Issues related to environmental protection are regulated by the Environmental Protection Law of the People's Republic of China, adopted on December 26, 1989. Article 4 of the Law stated that state plans related to environmental protection must be incorporated into national economic and social development plans. And "The state shall adopt economic and technological policies and measures favorable for environmental protection so as to coordinate the work of environmental protection with economic construction and social development". ${ }^{8}$ These solutions gave the priority of economic growth over environmental protection.

In April 2014, the government amended its environmental law. It now has 70 provisions, compared to the 47 in the existing law. The 2014 Revisions to China's Environmental Protection Law state that environmental protection is a basic national policy and discussed the promotion of ecological civilization in China (推进 生态文明建设, tuijin shengtai wenming jianshe). Article 4 said that the state shall adopt economic and technical policies and measures favorable to environmental protection so as to coordinate economic and social development with environmental protection. ${ }^{9}$ The key amendment related to the coordinating economic and social development with environmental protection. So far, economic growth remains China's priority at the expense of the environment. The document that will be prepared analyzes the impact of environmental changes on the public health. The new law imposes stiffer penalties for officials who fail to enforce environmental laws, for example, local officials may be demoted or dismissed for misconduct. The law also punishes polluting enterprises and public institutions. ${ }^{10}$

In his report to the $17^{\text {th }}$ Party Congress in 2007, the General Secretary of the Communist Party of China, Hu Jintao, said that efforts should be made to improve energy, resources, ecological and environmental conservation and enhance China's capacity for sustainable development. He emphasized the importance of ecological progress. ${ }^{11}$ In 2012 at the 18th Congress Hu Jintao put forward the concept of building an ecological civilization (生态文明, shengtai wenming). He outlined the priorities across six major areas, including completing pollution reduction tasks, giving priority to environmental protection to optimize economic development, improving environmental quality and safeguarding public health, improving environmental protection in rural area, rehabilitating major eco systems, and introducing indicator systems that will be incorporated into evaluation system of local governments. ${ }^{12}$

8 中华人民共和国环境保护法 (Zhonghua Renmin Gongheguo huanjing baohu fa), Ministry of Environmental Protection of the People's Republic of China, 26.12.1989, http://www.zhb. gov.cn/ztbd/rdzl/2010sdn/zcfg/201001/t20100113_184209.htm (access: 01.02.2016).

9 中华人民共和国环境保护法自2015年1月1日起施行 (Zhonghua Renmin Gongheguo huanjing baohu fa zi 2015 nian 1 yue 1 ri qi shixing), The Central People's Government of the People's Republic of China, 24.04.2014, http://www.gov.cn/xinwen/2014-04/25/content_2666328. htm (access: 01.02.2016).

${ }^{10}$ Ibidem.

11 胡锦涛在党的十七大上的报告 (Hu Jintao zai dang de shiqi da shang de baogao), Xinhua, 24.10.2007.

12 胡锦涛在中国共产党第十八次全国代表大会上的报告 (Hu Jintao zai Zhongguo Gongchandang di shiba ci quanguo daibiao dahui shang de baogao), Xinhua, 17.11.2012. 


\section{POLLUTION PREVENTION POLICY: PREVENTION AND CONTROL OF ATMOSPHERIC POLLUTION}

The low quality of the air in China remains a serious cause for concern. China currently ranks as the world's largest emitter of greenhouse gases. It accounts for nearly $30 \%$ of global CO2 emissions, mainly from burning fossil fuels (table 1). According to BP, China's carbon dioxide emissions are projected to increase by $37 \%$ by 2035 , when it will account for $30 \%$ of total world per capita emissions. ${ }^{13}$ On the other hand, it is worth noting that per capita $\mathrm{CO} 2$ emissions in China are relatively low, especially compared to developed countries (table 2). The major sectors contributing to China's carbon emissions, manufacturing and power generation, are responsible for $85 \%$ of country's total carbon emissions. Additionally, about $25 \%$ of carbon emissions in China are caused by manufacturing products that are consumed abroad. ${ }^{14}$

Table 1: CO2 emissions from fossil fuel use and cement production 1970-2014 (ton (Mg)

\begin{tabular}{|c|c|c|c|c|c|}
\hline & 1980 & 1990 & 2000 & 2010 & 2014 \\
\hline China & 27648 & 2411402 & 3746109 & 9009136 & 10540750 \\
\hline World & 19847474 & 22515632 & 25610746 & 33607885 & 35669108 \\
\hline
\end{tabular}

Source: Global CO2 emissions from fossil fuel use and cement production 1970-2014, EDGARv4.3, European Commission, Joint Research Centre (JRC)/PBL Netherlands Environmental Assessment Agency.

Emission Database for Global Atmospheric Research (EDGAR), release version 4.3. http://edgar.jrc. ec.europe.eu, 2015 forthcoming http://edgar.jrc.ec.europa.eu/overview.php? $\mathrm{v}=\mathrm{CO} 2 \mathrm{ts} 1990-2014 \&$ sort=des9 (access: 01.02.2016).

Particulate matter (PM), nitrogen oxides (NOx), and sulfur dioxide (SO2) are the major air pollutants. China is the largest PM, NOx and SO2 emitter in the world. Greenpeace has stated that more than $80 \%$ (293 cities) of 367 cities it monitored in 2015 did not reach National Ambient Air Quality Standard level two limit of $35 \mu \mathrm{g} / \mathrm{m} 3$ (micrograms per cubic meter). The national average concentration of PM2.5 in the monitored cities was $50.2 \mu \mathrm{g} / \mathrm{m} 3$. Of 31 provinces (autonomous regions and municipalities directly under the central government), only six met second grade NAAQS levels, i.e., annual average PM2.5 concentrations of less than $35 \mu \mathrm{g} / \mathrm{m} 3$ (Guangdong, Guizhou, Fujian, Yunnan, Tibet, and Hainan). Air pollution levels fell in most Chinese cities last year. Annual average levels of PM2.5 in 2015 dropped by $10.3 \%$ according to official data from 189 cities. $^{15}$

${ }^{13}$ BP Energy Outlook 2035: Country and regional insights - China, BP, http://www.bp.com/ content/dam/bp/pdf/energy-economics/energy-outlook-2015/Country_insights_China_2035.pdf (access: 01.02.2016).

${ }^{14}$ Zhu Liu, China's Carbon Emissions Report 2015, Belfer Center for Science and International Affairs, Harvard Kennedy School, May 2015, http://belfercenter.ksg.harvard.edu/files/ carbon-emissions-report-2015-final.pdf (access: 01.02.2016).

${ }^{15}$ A Summary of the 2015 Annual PM2.5 City Rankings, Greenpeace, 30.12.2015, http:// www.greenpeace.org/eastasia/Global/eastasia/publications/reports/climate-energy/2015/GPEA\%20 
Table 2: Per capita CO2 emissions from fossil fuel use and cement production 1970-2014 (ton $(\mathrm{Mg}) \mathrm{CO} 2$ per capita and per year)

\begin{tabular}{|c|c|c|c|c|c|}
\hline & 1980 & 1990 & 2000 & 2010 & 2014 \\
\hline China & 1.6 & 2.1 & 2.9 & 6.6 & 7.6 \\
\hline World & - & 4.2 & 4.2 & 4.9 & 4.9 \\
\hline
\end{tabular}

Source: Global per capita CO2 emissions from fossil fuel use and cement production 1970-2014, EDGARv4.3, European Commission, Joint Research Centre (JRC)/PBL Netherlands Environmental Assessment Agency. Emission Database for Global Atmospheric, 25.11.2015, http://edgar.jrc.ec.europa.eu/ overview.php?v=CO2ts_pc1990-2014 (access: 01.02.2016).

Table 3: 2015 air quality ranking by province

\begin{tabular}{|c|c|c|}
\hline Rank & Province level region & $\begin{array}{c}\text { Average PM2.5 } \\
\text { Concentration } 2015\left(\mu \mathrm{g} / \mathrm{m}^{3}\right) \\
\end{array}$ \\
\hline 1 & Henan & 80.7 \\
\hline 2 & Beijing & 80.4 \\
\hline 3 & Hebei & 77.3 \\
\hline 4 & Tianjin & 71.5 \\
\hline 5 & Shandong & 66.4 \\
\hline 6 & Hubei & 65.9 \\
\hline 7 & Jiangsu & 56.6 \\
\hline 8 & Shanxi & 56.4 \\
\hline 9 & Anhui & 55.1 \\
\hline 10 & Chongqing & 55.0 \\
\hline 11 & Liaoning & 55.0 \\
\hline 12 & Jilin & 54.4 \\
\hline 13 & Shanghai & 53.9 \\
\hline 14 & Xinjiang & 53.7 \\
\hline 15 & Hunan & 52.5 \\
\hline 16 & Shaanxi & 52.0 \\
\hline 17 & Zhejiang & 47.7 \\
\hline 18 & Sichuan & 46.7 \\
\hline 19 & Ningxia & 45.8 \\
\hline 20 & Jiangxi & 42.8 \\
\hline 21 & Qinghai & 42.6 \\
\hline 22 & Gansu & 41.2 \\
\hline 23 & Inner Mongolia & 41.0 \\
\hline 24 & Guangxi & 40.2 \\
\hline 25 & Heilongjiang & 39.4 \\
\hline 26 & Guangdong & 34.0 \\
\hline 27 & Guizhou & 31.7 \\
\hline 28 & Fujian & 28.7 \\
\hline 29 & Yunnan & 28.0 \\
\hline 31 & Tibet & 25.4 \\
\hline 31 & Hainan & 19.3 \\
\hline
\end{tabular}

Source: A Summary of the 2015 Annual PM2.5 City Rankings, Greenpeace, 30.12.2015.

2015\%20City\%20Rankings_briefing_int.pdf(access: 01.02.2016). 
In 2012 China surpassed the United States as the world's largest emitter of nitrogen oxide. In that time emissions grew to 23.378 million tons. ${ }^{16}$ The Chinese government has stated that the overall emission of sulfur dioxide (SO2) in 2014 was 19 million tons, and down from 25 million tons in 2005 . Nonetheless the real level could be twice as high, because of underreported emissions of the pollutant from burning coal. Luo Jianhua, secretary general of the China Environment Chamber of Commerce, a non-profit organization controlled by the government, underlined that the government statistics ignore $\mathrm{SO} 2$ emissions from facilities such as steel and cement factories and private boilers heating homes in winter. ${ }^{17}$

The 12th Five Year Plan (2011-2015) underlined the main objectives of improving the country's energy efficiency. Key goals included the reduction of energy consumption per GDP unit by $16 \%$ within five years, reduction of carbon dioxide emissions by $17 \%$ in the 2010-2015 compared to 2005 emissions as well as the reduction of carbon dioxide emission by $40-45 \%$ by 2020 .

In June 2015 Chinese Prime Minister Li Keqiang declared during his visit to Paris that China will aim to cut its GHG emissions per unit of gross domestic product by $60-65 \%$ from the 2005 level by 2030 . China also would increase the share of non-fossil fuels in primary energy consumption to around $20 \%$ by 2030 , and reach its peak $\mathrm{CO} 2$ emissions around the same time. ${ }^{18}$

China also has to improve the monitoring system of greenhouse gas emissions and gradually create the basis for a national trading scheme for carbon dioxide emissions. It has already launched seven pilot local emissions trading schemes. These experiences will help to launch a national carbon emissions trading market in 2017. It will cover sectors like power generation, iron and steel, chemicals and cement. The carbon market will help China meet its goal of ensuring its emissions peak around $2030 .{ }^{19}$ The system still has a number of weaknesses, such as legal and administrative regulations, statistics, data collection, and monitoring and evaluation systems. Emission limits for different regions should be based on their economic development, industrial structure, and the awareness of citizens about environmental issues. Progress in this area will mainly depend on the determination of the authorities.

${ }^{16}$ China SCR Denitration Catalyst Industry Report, 2013-2016, PRNewswire, 8.01.2014, http:// www.prnewswire.com/news-releases/china-scr-denitration-catalyst-industry-report-2013-2016239231641.html (access: 01.02.2016).

${ }^{17}$ Kong Lingyu, Official Figures for Major Smog Pollutant Last Year 'Off by Half', Caixin Online, 18.11.2015, http://english.caixin.com/2015-11-18/100875924.html (access: 01.02.2016).

18 中国宣布后 2020 气候目标：碳排放强度下降 $60 \%-65 \%$ (Zhongguo xuanbu hou 2020 qihou mubiao: tan paifang qiangdu xiajiang), 北极星节能环保网 (Beijixing jieneng huanbao wang), 01.07.2015, http://huanbao.bjx.com.cn/news/20150701/636379.shtml (access: 01.02.2016).

${ }^{19}$ V. Volcovici, China to announce 2017 launch of carbon market, officials say, Reuters, 25.09.2015. 


\section{POLLUTION PREVENTION POLICY: RESOLVING SOIL POLLUTION AND RESTORATION PLANS}

China has a huge problem with soil contamination. The most serious threat is created mainly by industrial and agricultural activities. Waste water, dust, and waste that is a side effect of industrial activity lead to degradation of soils. They often contain considerable amounts of heavy metals and salts. Agricultural activity was also identified as a major source of pollution due to the use of fertilizers and organic, mainly pesticides and detergents. According to a report prepared jointly by the Ministry of Environmental Protection and the Ministry of Land and Resources, $16.1 \%$ of China's soil and $19.4 \%$ of its arable land is polluted. ${ }^{20}$

China is implementing a plan for the rehabilitation of the environment. The key challenges relate to returning farmland that has been idle for several years to forests and grassland, controlling sources of sandstorms, and growing shelter forests. China has significantly increased forest area during the last two decades. World Bank data show that forest areas covered $21.9 \%$ of the country's land in 2013 compared with $16.7 \%$ in $1990 .{ }^{21}$ China's forest area continues to increase. In recent years it has been promoting re-forestation projects. The plan underlined by the State Forestry Administration (SFA) planned to create 29.6 million hectares of new forest by the end of 2015. According to the SFA survey, China had 208 million hectares of forest in 2014 , covering $21.6 \%$ of the country, compared with $20.3 \%$ in $2010 .{ }^{22}$ Its goal is to increase forest cover to $23 \%$ by 2020 and $26 \%$ by $2050 .^{23}$

Another problem relates to the shrinking of wetlands. Because of rapid urban industrial development, nearly $9 \%$ of China's wetlands (3.39 million hectares) vanished during the 2003-2013 period (from 57 to 53.6 million hectares). This means that China lost about $3 \%$ of its national territory over the past decade. The number of threats to wetlands has grown. Today the major threats are pollution, excessive fishing and gathering, land reclamation, invasion of alien species, and occupation by infrastructure. ${ }^{24}$

China presented its first pilot projects to prevent heavy metal pollution of soils in 2014. Under the plan, the Ministry of Finance will subsidize soil pollution prevention and treatment in three cities in Hunan province, where 3.33 million

20 全国土壤污染状况调查公报 (Quan guo turang wuran zhuangkuang diaocha gongbao), The Ministry of Land and Resources of the People's Republic of China, 17.04.2014, http://www. mlr.gov.cn/xwdt/jrxw/201404/P020140417573876167417.pdf (access: 01.02.2016).

${ }^{21}$ Forest area (\% of land area): China, The World Bank, http://data.worldbank.org/indicator/ AG.LND.FRST.ZS (access: 01.02.2016).

${ }^{22}$ Yang Yao, Shrinking of wetlands spurs call for regulation, "China Daily", 14.01.2014.

23 中共中央国务院矢于加快林业发展的决定 (Zhonggong zhongyang guowuyuan guanyu jiakuai linye fazhan de jueding), Xinhua, 25.06.2003, Xinhua, http://www.china.com.cn/chinese/ PI-c/401953.htm (access: 01.02.2016).

24 我国湿地面积比十年前减少339万公顷 (Woguo shidi mianji bi shi nian qian jianshao 339 wan gongqing), Xinhua, 13.01.2014, http://news.xinhuanet.com/2014-01/13/c_118939947. htm (access: 01.02.2016). 
hectares of farmland is too polluted to farm. The Ministry of Agriculture will control the contamination of soils by heavy metals. In its 12th Five-Year Plan (2011-2015), the Chinese government pledged to spend 30 billion yuan on the clean-up and prevention of soil pollution. However, it seems it is just a drop in the ocean. Lan Hong, a professor at the Renmin University's School of Environmental and Natural Resources said that to solve the problem China needs to spend 140 billion yuan. He pointed out problems such as the negative role of local officials in environmental management and vaguely drafted regulations stipulating the responsibility of polluters. ${ }^{25}$

China has around 135 million hectares of arable land in total, but the amount has been systematically reduced due to urbanization, industrialization, and pollution. It is obvious that soil pollution reduces the quality of crops. In "China Daily" Li Chenggang emphasized that the major task for government is to ensure people access to enough food. He noted that urbanization and industrialization have led to an "increasingly prominent" contradiction between urban construction and preservation of arable land. ${ }^{26}$

A survey by Luo Yongming, a senior soil expert at the Chinese Academy of Sciences, showed that over the past few years many polluting companies from Jiangsu, Liaoning, Guangzhou, Chongqing, and other areas had relocated, leaving behind contaminated land. It becomes a huge problem, because these factory sites are mostly chosen for real estate locations. ${ }^{27}$

Chinese scientists have warned that soil pollution is likely to reduce food supplies. For example, rice is a staple food for two-thirds of the Chinese population. In 2014, the country produced around 207 million tons of rice, compared with 179 million tons ten years before..$^{28}$ About $10 \%$ of China's rice yield may be contaminated by heavy metals, mainly poisonous cadmium. People living in southern China, where rice is a staple, are more at risk of cadmium poisoning than the rest of the population. ${ }^{29}$

Local officials lack the incentive to implement directives related to sustainable farming. Gao Shengda, secretary of the China Environmental Remediation Association, said that there is a lack of both experience and legislation. China needs an action plan for prevention and treatment of soil pollution and a better

${ }^{25}$ K. Chen, S. Reklev, China begins soil pollution clean-up amid doubt over funding, Reuters, 11.04.2014.

${ }^{26}$ Li Chenggang, Food security more than just quantity, "China Daily", 25.12.2013.

${ }^{27}$ Gao Shengke, Wang Kai, The houses built on China's 'poisoned' land, Chinadialogue, 5.06.2013, https://www.chinadialogue.net/article/show/single/en/6070-The-houses-built-on-China-s-poisoned-land (access: 01.02.2016).

${ }^{28}$ Rice production in China between 2004 to 2014 (in million tons), Statista (The Statistics Portal), http://www.statista.com/statistics/242364/rice-production-in-china/ (access: 01.02.2016).

${ }^{29}$ Gong Jing, Heavy Metals Tainting China's Rice Bowls, Caixin Online, 16.02.2011, http:// english.caixin.com/2011-02-16/100226177.html?p1 (1.02.2016). 
pollution monitoring system. ${ }^{30}$ In July 2015, Li Ganjie, vice-minister of environmental protection, declared that a draft of the soil pollution action plan had been submitted to the State Council. ${ }^{31}$

\section{POLLUTION PREVENTION POLICY: PREVENTION AND SOLUTIONS TO WATER SCARCITY AND POLLUTION}

Shortages of water have reached crisis levels in China as a result of rapid economic development. The problem of water scarcity mainly concerns the north of the country. The areas south of the Yangtze River account for over $36.5 \%$ of the country's total territory and $81 \%$ of its total water resources, while the areas north of the Yangtze, which make up $63.5 \%$ of China, have only $19 \%$ of water resources. ${ }^{32}$ It worth adding that around $45 \%$ of the population live in the north. According to Chinese experts, per capita water resources will drop to 1760 cubic meters by 2030 , close to 1700 cubic meters, the internationally recognized benchmark for water shortages. ${ }^{33}$ Demand for water is associated with the increase in population and results fundamentally from rapid economic development. It moves towards further industrialisation and urbanisation.

China must create a pricing system that reflects water scarcity, especially in urban spheres. In 2014 the National Development and Reform Commission introduced a plan for reforming rural water prices that will help to better conserve water resources. The plan has proposed a three-tier tariff system. The lowest lower tier will be paid by nearly $80 \%$ of urban households (base rate). The second tier, involving $15 \%$ of households, will pay 1,5 times the base rate, and the third tier, the $5 \%$ heaviest consumers, will pay 3 times the base rate for water. ${ }^{34}$ Prices for water are still low in China. A 2011 survey by Global Water Intelligence said water cost 46 cents a cubic meter at that time, compared with a global average

${ }^{30}$ Zhang Chun, China "lacks experience" to clean up its polluted soil, Chinadialogue, 14.04.2014, https://www.chinadialogue.net/article/show/single/en/6897-China-lacks-experienceto-clean-up-its-polluted-soil (access: 01.02.2016).

${ }^{31}$ Cheng Yingqi, Strategy outlined to prevent, treat soil pollution, "China Daily", 14.07.2015.

${ }^{32}$ Yang Mu, Weng Cuifen, China Recycled Water/ Water Treatment Industry in the Age of Water Crisis, [in:] Yang Mu, Yu Hong (eds.), China's Industrial Development in the 21st Century, World Scientific Publishing, Singapore, 2011, p. 103.

${ }^{33}$ China Warned of Water Crisis by 2030, Xinhua, China.org.cn, 6.06.2002, http://www. china.org.cn/english/SO-e/33957.htm (access: 01.02.2016).

34 国家发展改革委、住房城乡建设部发文部署各地加快建立完善居民阶梯水价制 度 (Guojia fazhan gaige wei, zhufang chengxiang jianshe bu fawen bushu gedi jiakuai jianli wanshan jumin jieti shuijia zhidu), 3.01.2014, http://www.sdpc.gov.cn/xwzx/xwfb/201401/ t20140103_574362.html (access: 01.02.2016). 
of 2.03 USD. Chinese consumers spent only $0.5 \%$ their income on water tariffs compared to $2.8 \%$ in the U.S. ${ }^{35}$

Deterioration of drinking water quality and water pollution continues to be a major problem. UNICEF and WHO estimate that there are still 108 million people without access to improved sources of drinking water. ${ }^{36}$ Therefore, beginning in 2011 the central government launched several programs related to resolving the rural drinking water safety problem. In 2012 Yan Guanyu, deputy director of the China Irrigation and Drainage Development Center under the Ministry of Water Resources, proclaimed that about 298 million rural residents will gain access to safe drinking water by $2015 .{ }^{37}$

But it worth to emphasizing that $76 \%$ of China's population already had access to improved sanitation and $95 \%$ of them to improved drinking water sources by $2015 .^{38}$

Seven major river systems, 28 major lakes, and offshore waters are seriously polluted. River water quality in China is measured in six levels (grade I to Grade $\mathrm{V}$ and another grade called worse than Grade V). Only Grade I and II water can be used as drinking water sources.

Table 4: Five grades of water quality in China

\begin{tabular}{|l|l|}
\hline Grade I & $\begin{array}{l}\text { Water source } \\
\text { National Nature Protection Zone }\end{array}$ \\
\hline Grade II & $\begin{array}{l}\text { Domestic drinking water source (Class I) } \\
\text { Rare aquatic biology habitat } \\
\text { Egg-laying site for aquatic life forms } \\
\text { Feeding and preying site for baby fishes }\end{array}$ \\
\hline Grade III & $\begin{array}{l}\text { Domestic drinking water source (Class II) } \\
\text { Hibernation site, migration route and breeding site for aquatic life forms; } \\
\text { Swimming site }\end{array}$ \\
\hline Grade IV & $\begin{array}{l}\text { Water use for industry } \\
\text { Entertainment use where water does not touch the human body }\end{array}$ \\
\hline Grade V & $\begin{array}{l}\text { Agriculture use } \\
\text { Scenic body of water }\end{array}$ \\
\hline
\end{tabular}

Source: Chinese National Standard GB3838-2002, http://www.hzhbj.gov.cn/ UpData/201005/20100512220701690.pdf (access: 01.02.2016).; Ge Junjie, Bi Jun, Wang Shi, Zhang Bing, Water Environment Protection Management and Integrated Governance Policies in China, http://www.ide. go.jp/English/Publish/Download/Jrp/pdf/155_ch1.pdf (access: 01.02.2016).

${ }^{35}$ B. Spegele, W. Kazer, To Conserve Water, China Raises Prices for Top Users, "The Wall Street Journal”, 8.01.2014.

${ }^{36}$ World Water Day: World's poorest have least access to safe water-UNICEF, UNICEF, 21 III 2014, http://www.unicef.org/media/media_72899.html (access: 01.02.2016).

${ }^{37} 298 m$ more rural Chinese to have safe drinking water, Xinhua, "China Daily", 30.10.2012.

385 questions with Yang Zhenbo: Closing the gaps with improved water \& sanitation in China, UNICEF, 2.07.2015, http://www.unicef.cn/en/index.php?m=wap\&siteid=1\&a=show\&catid $=51 \&$ typeid $=74 \& \mathrm{id}=4419$ (access: 01.02 .2016 ). 
According to the National Environmental Monitoring Center (NEMC), in 2005 the water quality of seven major rivers--Yangtze River, Yellow River, Pearl River, Songhua River, Huaihe River, Haihe River and Liaohe River--was far from satisfactory. Grade I-III accounted for $41 \%$ of waters, grade IV-V accounted for $32 \%$, and worse than grade $\mathrm{V}$ accounted for $27 \%{ }^{39}$

Ministry of Water Resources data showed that $40 \%$ of Chinese rivers were seriously polluted and unfit for drinking after 75 billion tons of sewage and waste water were discharged into them in $2010 .{ }^{40}$

According to 2012 data, water quality ranged from Grade I-III in $69 \%$ of sections, grade IV-V in $21 \%$ of sections, and inferior to grade $\mathrm{V}$ in $10 \%$ of sections. ${ }^{41}$ The Pearl and Yangtze Rivers had fairly good water quality, while the Liaohe and Haihe Rivers were heavily polluted. Water quality monitoring conducted in 968 monitoring sections (sites) in 423 main rivers and 62 key lakes (reservoirs) under national monitoring assigned 3.4\% of waters to grade I, 30.4\% to grade II, $29.3 \%$ to grade III, $20.9 \%$ to grade IV, $6.8 \%$ to grade V, and $9.2 \%$ to lower than grade $\mathrm{V}^{42}$

According to Ministry of Land and Resources analysis, 59.6\% of sites in 2013 had poor or extremely poor water quality. ${ }^{43}$ Heavily polluted water supplies have resulted in the emergence of cancer villages. Chinese media and Internet sources have identified 459 cancer villages across 29 of China's 31 provincial units. ${ }^{44}$

China promotes sustainable management of water resources. Since 2002 it developed the integrated water resources management (IWRM) concept, one based on the cooperation of all sectors on sustainable water resources development and management. The Water Law of the People's Republic has stated that the administrative department for water resources under the State Council is responsible for unified management of and supervision over water resources

392005 Report on the State of the Environment in China, State Environmental Protection Administration, http://english.mep.gov.cn/down_load/Documents/200710/P020071023479859455977. pdf (access: 01.02.2016).

${ }^{40}$ Water shortage, pollution threaten China's growth, Xinhua, China.org.cn, 16.02.2012, http://www.china.org.cn/environment/2012-02/16/content_24653422.htm (access: 01.02.2016).

${ }^{41}$ MEP Releases 2012 Report on the State of the Environment in China: Overall Environmental Quality across China Maintained Stable but the Situation Remained Severe, The Ministry of Environmental Protection of the People's Republic of China, 4.06.2013, http://english.mep.gov. cn/News_service/news_release/201306/t20130607_253508.htm (access: 01.02.2016).

${ }^{42}$ MEP releases the 2014 Report on the State of Environment in China, The Ministry of Environmental Protection of the People's Republic of China, 4.06.2015, http://english.mep.gov.cn/ News_service/news_release/201506/t20150612_303436.htm (access: 01.02.2016).

复 我国地下水监测点较差和极差水质比例为 $59.6 \%$ (Woguo dixiashui jiance dian jiao cha he ji cha shuizhi bili wei 59.6\%), Xinhua, 4.06.2014, http://news.xinhuanet.com/live/201406/04/c_1110980565.htm (access: 01.02.2016).

${ }^{44}$ Lee Liu, Made in China: Cancer Villages, Environment: Science and Policy for Sustainable Development, III/IV 2010. 
throughout the country. ${ }^{45}$ In 2005 Liu Ning, chief engineer of the Ministry of Water Resources, noted that without integrated water resources management (IWRM), China's total annual water supply will reach 800 to 900 billion cubic meters or hit the limit of the country's total water supply by 2030. About half of the water supply will be needed for irrigation to feed the growing population, 280 billion cubic meters for urban areas and industry, and 100 billion cubic meters for ensuring ecosystems. ${ }^{46}$

In 2011 the government implemented the China Most Stringent Water Resources Management System. To implement that, the State Council promulgated the "three red lines" policy (三条红线, san tiao hong xian) in early 2012; these outlined the targets for improve the water quantity usage, efficiency, and quality by 2030 . It set a limit of 635 billion cubic meters for water consumption by 2015, 650 billion cubic meters by 2020, and 700 billion cubic meters by 2030 . The plan seeks to improve water use efficiency attaining or approaching the advanced world level. Industries will reduce their water use per 10 thousand yuan of industrial added value by $30 \%$ below 2010 figures by 2015, 65 cubic meters by 2020 , and 40 cubic meters by 2030 . The effective utilization coefficients of farmland irrigation water will rise to $53 \%$ by $2015,55 \%$ by 2020 and above $60 \%$ by 2030 . The plan also seeks to achieve $95 \%$ adherence to water quality standards in industry by 2030 , compared to $46 \%$ in 2011 . The water quality compliance rate of water function zones will reach $60 \%$ by 2015 and $80 \%$ by $2020 .{ }^{47}$

According to the Action Plan for Water Pollution Prevention and Control, $70 \%$ of seven major rivers will be in good condition by 2020 , no lower than grade III. These figures will rise to $75 \%$ by 2030 . The plan has pledged to reduce "black and smelly water" (黑臭水体, hei chou shuiti) in urban areas at prefecture levels and above to $10 \%$ by 2020 and eliminate it by 2030 . The proportion of drinking water sources with the quality no lower than grade III in cities at prefecture level or above will reach $93 \%$ by 2020 and $95 \%$ by $2030 .{ }^{48}$

It seems the most challenging task for government is to improve water quality in the cities. So far the government has not presented guidelines how to measure what should be qualified as "black and smelly water". In this case local governments are using different standards. ${ }^{49}$

45 Water Law of the People's Republic of China, China.org.cn, 28.08.2002, http://www.china. org.cn/english/government/207454.htm (access: 01.02.2016).

${ }^{46}$ Liang Chao, Experts warn of water crisis, "China Daily", 20.04.2005.

47 国务院矢于实行最严格水资源管理制度的意见 (Guowuyuan guanyu shixing zui yange shui ziyuan guanli zhidu de yijian), The Central People's Government of the People's Republic of China, 16.02.2012, http://www.gov.cn/zwgk/2012-02/16/content_2067664.htm (access: 01.02.2016).

48 水污染防治行动计划 (Shui wuran fangzhi xingdong jihua), The Ministry of Environmental Protection of the People's Republic of China, 16.04.2015, http://www.mep.gov.cn/gkml/ hbb/qt/201504/t20150416_299173.htm (access: 01.02.2016).

${ }^{49}$ Kong Lingyu, Gov't Announces Grand Plans for Cleaning up Nation's Polluted Water, Caixin Online, 5.01.2015, http://english.caixin.com/2015-05-01/100805752.html (access: 01.02.2016). 


\section{SUMMARY - CHINA DECLARES WAR AGAINST POLLUTION}

The new leadership of the Chinese Communist Party has made the fight against pollution a priority. In March 2013, Chinese premier Li Keqiang declared war against pollution as he declared war against poverty and pledged to fight it with the same determination. ${ }^{50}$ In September 2013 China unveiled the Airborne Pollution Prevention and Control Action Plan (2013-2017) that aims to significantly reduce coal consumption in absolute terms, shut down polluters, and promote cleaner production. China has set target to reduce by 2017 the concentration of PM10 by $10 \%$ compared to 2012 for most cities and PM2.5 pollution by $25 \%, 20 \%$ and $15 \%$ for greater regions like Beijing, Shanghai and southern Guangdong. ${ }^{51}$

These objectives correspond to the China's energy development strategy for 2014-2020, introduced by the State Council in November 2014. It aims to reduce energy consumption per unit of GDP by improving energy efficiency and developing clean energy sources. China intends to reduce its $66 \%$ dependence on coal for power generation to $62 \%$ and raise the share of non-fossil fuel in primary energy to $15 \%$ and natural gas to $10 \%$ by $2020 .^{52}$

It seems that the former GDP focused growth model that ignored environmental protection has moved gradually into the past. The targets of environmental policy in China are mainly related to the implementation of the sustainable development concept. China integrates these targets within the various sectoral policies based on promotion of environmentally friendly production and consumption patterns as well as improving management systems. China also conducts a campaign to encourage an environmentally friendly lifestyle and initiatives to promote sustainable consumption. China still has to improve enforcement of environmental laws and regulations, environmental management systems, as well as the division of competences between the central and local levels of government.

50 政府工作报告. 2014年3月5日在第十二届全国人民代表大会第二次会议上国务院总 理 李克强 (Zhengfu gongzuo baogao. 2014 nian 3 yue 5 ri zai di shier jie quanguo renmin daibiao dahui di er ci huiyi shang guowuyuan zongli Li Keqiang), Xinhua, 14.03.2014.

${ }^{51}$ 国务院矢于印发大气污染防治行动计划的通知 (Guowuyuan guanyu yinfa daqi wuran fangzhi xingdong jihua de tongzhi), The Central People's Government of the People's Republic of China, 10.09.2013, http://www.gov.cn/zwgk/2013-09/12/content_2486773.htm (access: 01.02.2016).

52 能源发展战略行动计划（2014-2020年) (Nengyuan fazhan zhanlüe xingdong jihua (2014-2020 nian), The Central People's Government of the People's Republic of China, 19.09. 2014, http://www.gov.cn/zhengce/content/2014-11/19/content_9222.htm (access: 01.02.2016). 


\title{
POLITYKA OCHRONY ŚRODOWISKA W CHINACH: WYZWANIA I MOŻLIWOŚCI
}

\begin{abstract}
Abstrakt. W długoterminowych planach rozwoju Chin nacisk został położony na kwestie dotyczące ochrony środowiska. Chiny podkreślają, że mierzenie wzrostu gospodarczego musi brać pod uwagę również koszty środowiskowe. Plany rozwoju gospodarczego zostały w następstwie tego sprzężone z planami ochrony środowiska. Strategia niskoemisyjnych rozwiązań musi prowadzić do określenia nowego modelu rozwojowego pozwalającego z jednej strony chronić środowisko naturalne, a z drugiej utrzymywać konkurencyjność rodzimej gospodarki.
\end{abstract}

Słowa kluczowe: Chiny, ochrona środowiska, polityka środowiskowa, rozwój samopodtrzymujący 